\title{
Serum Proteins and Disazo Dye Teratogenesis '
}

\author{
ALLAN R. BEAUDOIN \\ Department of Anatomy, the University of Michigan, Ann Arbor, Michigan
}

\begin{abstract}
Serum proteins of pregnant rats were analyzed by paper electrophoresis following administration of the teratogenic disazo dyes trypan blue, Evans blue, Niagara blue $4 \mathrm{~B}$, Niagara sky blue $6 \mathrm{~B}$, Congo red, and Niagara blue 2B. Sera were obtained from blood taken by cardiac puncture just before dye injection, 48 hours after dye injection, and again at autopsy. All of the dyes tested caused a reduction in serum albumin and total protein concentration and an elevation in the concentration of beta or alpha-2 globulins at some time during pregnancy. The remaining serum fractions reacted variably to the dye treatment. In spite of the rather consistent results presented in this paper, and similar findings reported for other teratogens, there is no direct proof that altered serum proteins, per se, are causally related to the production of malformations.
\end{abstract}

Clinical and experimental observations suggest that altered electrophoretic patterns of serum proteins may accompany pregnancies terminating in the birth of malformed offspring. Abnormal electrophoretic patterns were noted in the serum proteins of rats treated with various teratogens (see table 1 for references). Fairly consistent among these were decrease in serum albumin and increase in serum alpha globulin. Similar changes were found in sera from high-risk pregnant women (Langman et al., '59), in 78\% of whom pregnancy ended in abortion, birth of premature infants with or without malformation, or abnormal full-term children. These observations have generated speculation about the possible relation of altered serum proteins and congenital malformations.

The results reported below were obtained during an investigation of the teratogenic activities of several disazo dyes structurally related to trypan blue (Beaudoin, '68). They support previously observed effects of certain teratogens on serum proteins in rats and suggest a relation between teratogenic potency and altered protein metabolism.

\section{MATERIAL AND METHODS}

Virgin female Wistar Albino rats (Albino Farms, Red Bank, New Jersey) were used. They were maintained on Rockland Complete Rat Diet ad libitum, with supplemental feedings of lettuce. Day 0 of pregnancy was considered to begin on the morning sperm were found in the vaginal smear. On day 8 pregnant rats received an intraperitoneal injection of a $2 \%$ aqueous solution of the dye to be tested. The dose was calculated on the basis of the maternal weight on day 8 . The doses used were $14 \mathrm{mg} / 100 \mathrm{~g}$ for the more potent dyes, trypan blue, Evans blue, and Niagara blue $4 \mathrm{~B}$; and $20 \mathrm{mg} / 100 \mathrm{~g}$ for the less potent dyes, Niagara sky blue 6B, Congo red, and Niagara blue 2B (Beaudoin, '68). All dyes were purchased from Matheson, Coleman and Bell Co., Norwood, Ohio.

Blood was withdrawn via cardiac puncture just before dye was injected, 48 hours after dye injection, and at the time of autopsy. Sera were analyzed by the paperelectrophoretic method as described previously (Beaudoin, '66). Total protein content of the serum was measured with a Bausch and Lomb Serum Protein Meter.

Pregnancy was terminated on day 20 and the fetuses were recovered, weighed, and fixed in Bouin's fluid. The types and frequencies of the malformations produced are listed in table 2 and have been previously reported (Beaudoin, '68).

\section{RESULTS}

Table 3 summarizes the results of this experiment. The dyes are listed in the order of decreasing teratogenicity. Blood

1 Supported by USPHS grant HD 00400 from the National Institute of Child Health and Human Development. 
TABLE 1

The effect of teratogens on serum protein fractions in rats

\begin{tabular}{lccccccc}
\hline \multirow{2}{*}{ Teratogen } & $\begin{array}{c}\text { Total } \\
\text { protein }\end{array}$ & \multicolumn{5}{c}{ Globulins } & \multicolumn{2}{c}{ Reference } \\
\cline { 3 - 6 } & Gamma & Beta & Alpha & Albumin & \\
\hline X-ray & - & - & 0 & + & - & Winkler and Paschke ('56) \\
Aminopterin & - & - & 0 & + & - & Rohatgi and Banerjee ('59) \\
Folic acid deficiency & - & - & - & - & - & Mulgaonkar and Sreenivasan ('58) \\
Trypan blue & - & 0 & + & + & - & Dijkstra and Gillman ('60) \\
Carbutamide & - & 0 & - & + & - & Christie ('64) \\
\hline
\end{tabular}

+ , Increase in concentration; - , decrease; 0 , no change.

TABLE 2

Incidence (\%) of malformations following a teratogenic dose of dye

\begin{tabular}{|c|c|c|c|c|c|c|}
\hline Malformation & $\begin{array}{c}\text { Trypan } \\
\text { blue }\end{array}$ & $\begin{array}{l}\text { Evans } \\
\text { blue }\end{array}$ & $\begin{array}{l}\text { Niagara } \\
\text { blue } 4 \mathrm{~B}\end{array}$ & $\begin{array}{c}\text { Niagara } \\
\text { sky blue } 6 \mathrm{~B}\end{array}$ & $\begin{array}{l}\text { Niagara } \\
\text { blue 2B }\end{array}$ & $\begin{array}{l}\text { Congo } \\
\text { red }\end{array}$ \\
\hline Apparent anophthalmia & 29.8 & 37.5 & 15.1 & 58.5 & 42.2 & 18.2 \\
\hline Hydrocephalus & 15.4 & 15.6 & 33.4 & 15.1 & 31.6 & 33.2 \\
\hline Exencephaly & 15.1 & 6.3 & 6.5 & 3.8 & - & - \\
\hline Microphthalmia & 5.7 & 9.4 & 6.5 & 11.3 & - & 21.2 \\
\hline Vertebral & 5.7 & 6.3 & 4.3 & 1.9 & - & - \\
\hline Encephalomeningocele & 5.4 & 3.1 & 6.5 & - & - & - \\
\hline Megalophthalmia & 3.9 & - & 1.7 & 1.9 & - & - \\
\hline Absent tail & 3.6 & - & 10.8 & - & - & $\ldots$ \\
\hline Other & 15.4 & 21.8 & 15.2 & 7.5 & 26.2 & $27.3^{1}$ \\
\hline \multicolumn{7}{|l|}{ Mean number of } \\
\hline malformations per fetus & 1.7 & 1.2 & 1.6 & 1.2 & 1.1 & 1.1 \\
\hline
\end{tabular}

was drawn from each rat three times, once on each of days 8,10 , and 20 . Mean values for serum protein content were calculated for each of these days, in both control and experimental groups. Since initial values (day 8) for protein content varied somewhat from group to group statistical analysis was limited to the results within each group. Nevertheless this did permit comparison of serum protein changes in control and dye-treated pregnancies. Cardiac puncture, at the intervals used in this study, did not significantly alter the serum proteins in nompregnant rats (Beaudoin, unpublished).

On day 20 , control rats exhibited a significant decrease in the serum concentration of gamma and beta globulins, compared with values on day 10 . During this same period alpha-1 globulin significantly increased but concentrations of total protein and all other serum protein fractions were essentially unchanged.
Total protein concentration decreased significantly within 48 hours of treatment with all dyes, but returned to or surpassed preinjection levels by day 20 , except in animals treated with Niagara blue $2 \mathrm{~B}$, in which the concentrations remained low. By day 20 gamma globulin concentration had decreased by more than half in control rats and those injected with Congo red or Niagara blue 2B. The remaining dyetreated rats exhibited either no change in gamma globulin or only a moderate decrease. Beta-globulin values increased significantly following injection with four of the six dyes, the exceptions being Congo red and Niagara blue 2B. The concentration of alpha-3 globulin increased significantly following injection of Evans blue and Niagara sky blue $6 \mathrm{~B}$, but was relatively unaffected by the other dyes. Fortyeight hours after injection all dyes, except Niagara blue 4B, had caused an elevation in alpha-2 globulin concentration, which 


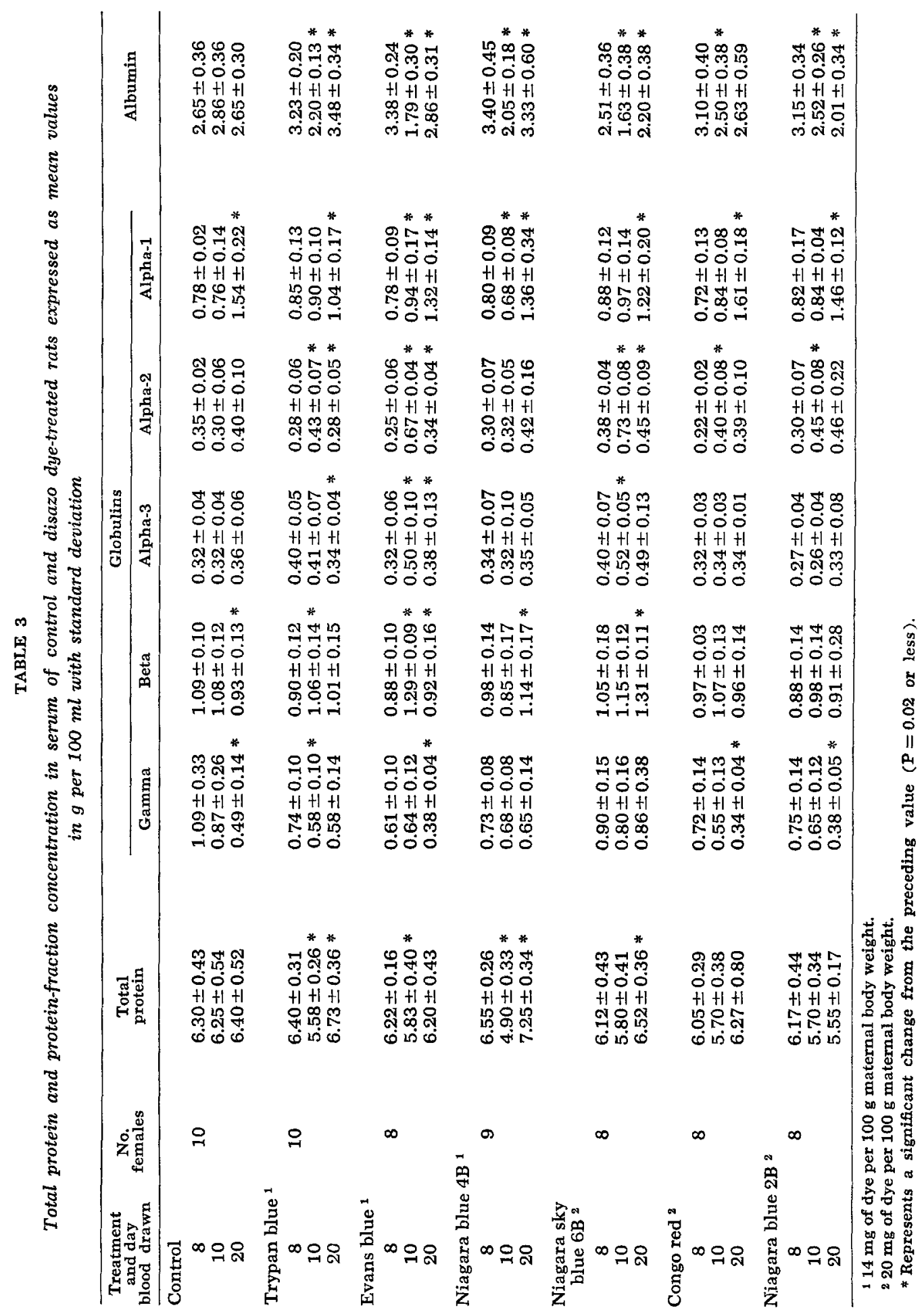


persisted to day 20 in rats injected with Congo red and Niagara blue 2B. A twofold increase in alpha-1 globulin concentration occurred in control animals and those treated with Niagara blue 4B, Congo red, and Niagara blue 2B, while in animals treated with trypan blue, Evans blue, and Niagara sky blue 6B the increase was only about $20 \%$. Albumin decreased in all rats by 48 hours after treatment, but by day 20 the concentration of albumin had almost returned to pretreatment levels, except in rats treated with Niagara blue $2 \mathrm{~B}$.

In general the three more potent teratogenic dyes (trypan blue, Evans blue, Niagara blue $4 \mathrm{~B}$ ) caused more pronounced alterations in the serum protein fractions than did the three less potent ones (Niagara sky blue 6B, Congo red, Niagara blue $2 \mathrm{~B}$ ).

\section{DISCUSSION}

There is no doubt that some teratogens can affect maternal protein metabolism in rats, as reflected by alterations in the electrophoretic patterns of the serum proteins. Changes in the proteins of the blastocyst fluid in rabbit embryos from trypan bluetreated mothers mimic the maternal serum protein changes (Hommes, '59; Beaudoin and Ferm, '61). Rat fetuses from trypan blue-treated mothers also exhibit altered serum proteins during development (Beaudoin and Kahkonen, '63). It is interesting to note that changes in the fetal serum proteins, induced by trypan blue, do not persist into the juvenile period (Beaudoin, '66). This suggests a maternal influence over fetal protein metabolism, perhaps by the liver. It is currently held that these alterations in the proteins of maternal serum, blastocyst fluid, and fetal serum represent secondary effects of the teratogen and are not involved in the production of malformations (Dijkstra and Gillman, '60; Fister and Benas, '60; Beaudoin, '66). Certainly the altered serum proteins are not in themselves teratogenic (Beaudoin and Roberts, '65).

Disazo dyes consistently cause a fall in total serum protein and serum albumin at some time during gestation in rats. The same effect has been reported with other teratogens (table 1). All dyes caused elevations in beta or alpha-2 globulin concen- tration at some time during pregnancy. It is not possible to make direct comparisons between this response and changes in the globulins caused by other teratogens because of the lack of uniformity in the designation of the alpha and beta subfractions. However, all but one of the teratogens listed in table 1 caused an elevation in the serum alpha globulins. The serum protein fractions that changed following treatment with the disazo dyes always changed in the same direction (increase or decrease). The principal difference among the dyes tested was in the magnitude of the change produced. The teratogenically most potent dyes caused the greatest disturbance in maternal serum proteins.

It can be concluded that treatment of rats with a teratogenic dose of any one of the six disazo dyes used in this experiment affects maternal protein metabolism and that the extent of this effect depends upon the teratogenic potency of the dye used. In spite of this rather consistent effect there is no evidence, to date, that a causal relation exists between the teratogenic effects of the dye and its effect on maternal protein metabolism.

\section{LITERATURE CITED}

Beaudoin, A. R. 1966 The effect of trypan blue on the postnatal development of serum proteins. Life Sci., 5: 673-677.

1968 The teratogenic activity of six disazo dyes in the Wistar albino rat. Proc. Soc. Exp. Biol. Med., 127: 215-219.

Beaudoin, A. R., and V. Ferm 1961 The effect of disazo dyes on protein metabolism in the pregnant rabbit. J. Exp. Zool., 147: 219-226.

Beaudoin, A. R., and D. Kahkonen 1963 The effect of trypan blue on the serum proteins of the fetal rat. Anat. Rec., 147: 387-396.

Beaudoin, A. R., and J. Roberts 1965 Serum proteins and teratogenesis. Life Sci., 4: 13531358.

Christie, G. A. 1964 The teratogenic activity of trypan blue, and its effect on the thyrohypophyseal axis in the rat. J. Anat., 98: 377384.

Dijkstra, J., and J. Gillman 1960 Trypan blue concentration and protein composition in sera of rats injected repeatedly with trypan blue in relation to reticulosis and to reticulo-sarcoma. S. Afr. J. Med. Sci., 25: 119-131.

Fister, V., and A. Benas 1960 The influence of oral hypoglycemic agents (carbutamide and tol- 
butamide) on the serum proteins of normal rats. J. Endocr., 20: 320-324.

Hommes, O. R. 1959 Trypan blue in the rabbit. Acta Morph. Neerl. Scand., 2: 28-37.

Langman, J., H. van Drunen and F. Bouman 1959 Maternal protein metabolism and embryonic development in human beings. Am. J. Obst. Gyn., 77: 546-555.

Mulgaonkar, A. G., and A. Sreenivasan 1958 Alterations in rat serum in single deficiencies of folic acid and vitamin $\mathrm{B}_{12}$. Proc. Soc. Exp. Biol. Med., 98: 652-655.

Rohatgi, K., and S. Banerjee 1959 Serum lipoproteins and glycoproteins in aminopterin treated rats. Proc. Soc. Exp. Biol. Med., 102: 761-763.

Winkler, C., and G. Paschke 1956 Protein content and composition of rat serum as related to amount of whole body $\mathrm{x}$-radiation. Radiat. Res., 5: 156-161. 